\title{
ASSIGNMENT OF THE NEW TYPE OF ECOLOGICAL SERVICES FOR PROVIDING HUMAN SAFETY UNDER CONDITIONS OF URBAN ENVIRONMENT
}

\author{
Kateryna Vasiutynska \\ Department of Applied Ecology and Hydrogasdynamics \\ Odessa National Polytechnic University, \\ 1 Shevchenko ave., Odessa, Ukraine, 65044 \\ ekaterina.vasutinskaya@gmail.com
}

\begin{abstract}
The main aim of the study is to separate a new category of ecological services for providing human and environmental safety under conditions of accelerated urbanization in the system of eco-services.

Urbanization decreased the potential of ecological services and the set of provided functions at the expanse of absorbing essential territories of natural ecosystems and disturbing the ecological balance of the environment. The urbogenic environment that men made and natural dangerous phenomena intensify synergetically in models the new level of threats for both a human and all biotic and abiotic components.

There was offered to separate an integral safety service as a new type of eco-services, based on the principle of providing human safety through environmental one. It was demonstrated, that safety services will improve other categories of ecological services, widen the assortment, diversity and mutual dependence of functions.

There was presented the succession of steps for identifying and assessing safety services. Indicators and possible types of giving safe and high-quality drinking water to the population were given.

The demand for safety services will grow with the development of urbanization processes. Separation and provision of services by functions of the human protection against natural and men made threats increases the total potential of eco-services.
\end{abstract}

Keywords: ecological service, urboecosystem, safety, urban environment, natural capital, human life and health risk.

\section{Introduction}

Accelerated rates of urbanization both throughout the world and in Ukraine, where urbanization reached $69,2 \%$ in the last 2016 [1], determine the wide circle of problems, connected with degradation of the natural environment. The essence of urbanization is not only in increasing the number of the urban population, growth of the number and area of cities. The character of the territorial structure of regions, which socio-economic development is determined by the development of cities, is changing. This all result in concentration of the transport and industrial potential in cities, excessive energy consumption, production of a great amount of domestic and industrial wastes. Large cities are a kind of "torches" of emission of ozone-destructing and greenhouse gases, in such a way increasing risks of climatic changes.

The development of cities in many countries is accompanied by spreading and engaging suburban zones. That is why areas of suburban "green girdles" that have a great importance for saving ecological balance of a territory shorten. The appearance of urban agglomerations is especially noticeable in Ukraine. According to data of the World Bank [2], the formation of agglomerations, especially, in the center and west of the country, is connected with the intensive socio-economic development of regions and correspondent redistribution of a share of the urban and rural population.

The urbanization level increase over $30 \%$ essentially increases the anthropogenic-men made load on the environment [3], aggravates population's life and health threats.

One of approaches to raising the cities" stability is the use of "ecosystem services" for eliminating pollution and other ecological problems. The conception of eco-services appeared in 1997 for supporting the biological diversity by estimating its role in the human life and economy [4] on the base of ideas about methods of capitalization of natural resources. Approaches to estimating ecological services continuously develop throughout the world that was confirmed in the following documents of sustainable development: 
- MA-2005 «Millennium Ecosystem Assessment» under the aegis of UNEP [5];

- The project of the European community TEEB-2010 «The Economics of Ecosystems and Biodiversity: Ecological and Economic Foundation》〉 [6].

The Working Group on Mapping and Assessment on Ecosystems and their Services, created within the European Community, has a task to coordinate and control the observance of MA-2005. In the first report of the working group, accepted in April of 2013 [7], there was grounded the conceptual foundation that connects the biodiversity, condition of ecosystems with human welfare. At the same time there was elaborated the typology of ecosystems in Europe in correspondence with the Common International Classification of Ecosystem Services (CICES). At that the urboecosystem was separated as an ecosystem on the territory of urban agglomerations. The second report of MAES [8] presented parameters that may be used for juxtaposing and assessing the biodiversity, state of ecosystems and ecosystem services in correspondence with CICES.

For the practical use of the system of eco-services for human welfare, it is expedient to determine the character of ecosystem services, provided by the complete, dynamically developing urboecosystem. At that it is necessary to take into account that urbanization resulted in the abrupt intensification of toxicity, carcinogenicity of the urban environment that men made and natural dangerous synergetically intensify in. The urbogenic habitat models the new level of threats for both a human and all biotic and abiotic components of the urban system.

Safety requirements are completely agreed with the conception of sustainable development. At the continuous socio-economic growth, stability is attained at the expanse of integration of safety of the resource potential, ecological production, green energetics, innovations for increasing human welfare. Many-sided cooperation between urbanization, increased levels of threats to environmental safety and human needs raise the necessity in "restructurization" of the whole system of ecoservices.

Thus, the aim of our work is to develop the conception of ecological service of human and environmental safety as a new integral service under conditions of urbanization.

Within this aim the tasks to analyze the existent system of eco-services, providing welfare of urbanites to determine the mechanism of safety services, to identify functions and approaches to estimating new functions are set.

\section{Analysis of literary data and statement of the problem}

The most part of studies in this field has the common aim - to generalize information about the ecological condition of the territory of states, tendencies of their change, and also to reveal the type of human welfare dependence on the natural capital.

The conception of eco-system services is affiliated with other important directions of the European policy - complex impact assessment on the environment and stable development program. It widens possibilities of their joint practical use in EU and separate countries. As it was demonstrated by authors [9], the mutual integration of conceptions results in increasing the number of used parameters that allow to reach the necessary diversity and to favor the common aim of sustainable development.

Thus, work [10] considers the criteria of choosing such parameters that would favor their institutionalization and also have more reliability and relevance for the practical implementation.

Ecological services are reserves of the natural capital, combined with productive and human resources for providing human welfare. In such a way ES combine socio-economic systems with ecosystems by the direct effect of ecological functions and indirectly by the human activity in whole. As it is noted in [11], the human socio-economic activity stimulates the human need in ecological services. Giving the main number of services needs human capital reproduction. Let's note specially, that the authors related health and safety to parameters of HWB measuring. But the notion of safety is used exceptionally in the context of social services that is the cultural-esthetical category of ES.

The work for representing and estimating ecosystems and ecosystem services has the great importance for not only achieving aims in the field of supporting the biodiversity, but also for developing and implementing associated strategies in the field of saving water resources, climate, agriculture, forest and regional planning. 
Study [12] analyses parameters of ecosystem services in many countries on the base of 21 subglobal assessments within MAES. It was demonstrated, that disadvantages include informative limitedness and complications in using estimating indicators. The analysis of the work reveals distinct regularities in parameters and categories of ecosystem services. Thus, quality parameters and indicators prevail for providing services (especially, food products) at the global level, and quantitative ones - at the national level. Parameters of regulating services are presented most completely.

The experience of implementing the conception of ecosystem services in Germany is presented in work [13]. It was noted, that besides the well-developed landscape planning, strategies of climate protection and use of renewable energy sources develop too. Based on the analysis of 13 federal laws about climate protection and 26 regional statements there was estimated the degree of using ES conception. The authors offer to use advantages of renewable energy sources for climate protection and decrease of greenhouse gases emissions.

The rapid urbanization essentially influenced volumes of supplying and using most ecosystem services in the policy of different countries. Let's note that the decrease of the ecological services potential and essential losses from shortening their use are determined mainly by 2 factors:

1) urbanization expansion of essential territories of natural ecosystems beyond the urban territory;

2) degradation of internal urboecosystems under the pressure of the anthropogenic-men made impact.

Thus, researchers of Great Britain [14] demonstrated that the man driving force of global changes in the distribution of vitally important ecosystem services till 2050 will become the processes of rapid urbanization. There was studied the urbanization influence on the services, most important for Great Britain: mitigation of flood results, carbon storage and agricultural production. According to conclusions of authors [14], urbanization influences the ability to mitigate results and to decrease the frequency of floods especially negatively. It is explained by increasing impenetrable surfaces within urban buildings.

The absorption of territories of natural systems and ones of land use by urban agglomerations may result in the deficit of certain goods and services. Thus, the possible decrease of services, connected with agricultural production per capita was demonstrated in work [15].

The change of the type of land use under the pressure of spreading cities became the regular result of the fast-growing Chinese economy. The studies of authors [16] by methods GIS-technologies revealed the decrease of costs of ecosystem services in Tianjin district Binhai by 25,9\% for the period 1985-2010. The economic loss was near 3 bil yuans. The analogous conclusions were made in work [17] on the base of the analysis of four Chinese regions, where the urban expansion of natural and agricultural landscapes resulted in decreasing the cost of ecosystem services by 8,5 bil yuans in a year in average (in 1994-2003). Counteraction measures include landscape planning of urban agglomerations that keeps territories of natural systems [17].

The main direction of studies in the field of formation of ecosystem services of intraurban territories connects them with the green infrastructure [18-21], that realizes different functions of compensating natural and men made impacts.

Work [18] demonstrates that urboecosystem services, connected with vegetable communities, essentially influence the life quality of the urban population. The soil-vegetable coat, not covered by asphalt, generates most important functions of air filtration, creation of the favorable microclimate, noise reduction, drainage and cleaning of storm runoffs. Green zones create recreational and cultural values.

Further studies [19] prove the important role of the green infrastructure of cities in compensating emissions of greenhouse gases, assimilating water and air pollution, improving social health protection. Green plants participate in realizing almost all categories of urban ecosystem services. The provision of regulating services with the green infrastructure is based on the participation of water, carbon, nitrogen and other substances in biogeochemical cycles [20].

Many systems of parameters are applied for estimating ES, based on functions of green plants. Thus, in Romania [21], there was used the specific parameter of the green zone area per cap- 
ita, $\mathrm{m}^{2}$ /person. Conclusions about the necessity of planning green zones corresponding to the building density, transport infrastructure, geomorphological and other urban peculiarities were made.

Thus, the urban ecological infrastructure is considered as a key element in improving the life quality and creating proper conditions for the stable development of cities.

However, the use of the conception of ecosystem services as a practical instrument of the ecological policy in Ukraine as in other post-soviet countries is insufficiently studied. These studies mainly concern the development of mechanisms of estimating services, provided by natural [22], especially forest ecosystems [23]. Ukraine mainly develops the direction of the development of the economic mechanism of assessing ecosystem services [24]. Ukraine's participation in general European programs stimulates the development of the whole system of eco-services. Bases of assessing services of forest ecosystems and correspondent mechanisms of realizing payments for their use were elaborated under the aegis of the European Union and World Bank [25].

Summarizing, let's note that taking into account urbanization peculiarities, the necessity in researches in the field of urban eco-services became imminent in Ukraine long ago. The necessary condition of the stable growth of human welfare is safety provision as a base of the whole complex of economic services. That is why the identification of functions for providing human safety is timely and urgent.

\section{Methodology of studying and assessing ecological services}

Methodological bases of assessing ecosystem services [3-8, 10, 12, 16, 20, 22, 23, 25] are used in the work. The revelation of the economic importance of losses of the biodiversity for human welfare became a fundament for elaborating correspondent compensation mechanisms.

Functions of ecosystems are determined as a natural potential or potential for providing ecosystem services, realized at the existent demand. In such a way people use goods and services of ecosystems including food products, access to clean air and water, health, and first of all, safety. Economic estimations are used for ecosystem services. Monetary methods allow to measure the cost of ecosystems for human interests in the monetary expression. Non-monetary methods are suitable for accounting such values as health, education and other social ones.

The conception of eco-services differentiates methods of using ecosystems for creating human welfare in active or passive way in four categories $[5,10,20]$. Ecosystem services, used directly, are divided in three groups:

1. Providing services. At the beginning MAES document [5] related only products, produced by natural systems - vegetable food, sea products, water medicinal herbs, vegetable raw materials and so on to them. At including urbo- and other types of artificially regulated systems in the system of eco-services, the assortment of productive services became to include water in different branches of economy, biomass for renewable energy sources and so on.

2. Regulating services provide benefits from the climate regulation, quality of air and water, restoration of the soil-vegetable coat, prevention or mitigation of results of natural calamities. Let's note that natural processes of self-cleaning of natural environments take place even in ecosystems with the anthropogenic regulation (urboecosystems).

3. Cultural-esthetical and information services including educating, spiritual, recreational, scientific ones.

Supporting services form the fourth group of fundamental ecological processes, indirectly used by humans, which realization makes all eco-services possible. The base of supporting services is biogeochemical cycles with a certain share of compensation of flows of synthesis and decay of an organic substance. Just as a result of circulations, there takes place the soil-formation, initial products (vegetable mass) form, the balance of carbon dioxide and water is provided.

\section{Results. Assignment of safety services as an integral ecological service}

For today the structure of eco-services with four services $[4,5,8,18]$ cannot thoroughly reflect both the state of different types of ecosystems and methods of their use by a human. It especially concerns urbosystems that natural components are essentially transformed in, and functioning is almost completely managed by humans. 
Limitations of the existent model of ecological services are in the absence of profits and losses from using the environment as an inseparable component of own ecological niche, own habitat in whole by a human. Such situation doesn't reflect modern human requirements and needs to a habitat, especially in a case of the urban environment. The base of the high life quality is, first of all, safety guaranteeing, decrease of risks of health and welfare under specific conditions of the urbogenic-men made habitat.

The author creates the conception of separating a special category of given ecosystem services - safety ones, which main principle - human safety through environmental safety. The new category of ecosystem services qualitatively differs from the known ones by the fact that it estimates benefits and losses from using the whole system of natural, anthropogenic, men made factors of a habitat by a human. From the other side, services are integral and allow to provide functions of last four ones by keeping the necessary quality of all elements of the human's environment, providing the necessary safety level.

The block-scheme, presented on Fig. 1 gives the transformed structure of eco-services taking into account the implementation of the new category of ecological safety services.

The mechanism of services is in keeping human individual safety, based on decreasing diverse threats of life, health that is includes minimization of individual risks, and social ones - for the population. The mechanism of services for ecosystems is generated by complicated interactions of technical, social, natural and quasi-natural systems. As a result, there is formed the urbogenic landscape that provides one or another safety level for the population.

Functions, actively used for safety services: the decrease of risks of unfavorable ecological situations, natural and men made emergencies. Functions are used passively (indirectly) for keeping the high quality of the urban environment at the level, safe for life and health of the population. Thus, human vitally important needs are provided by safety of the natural environment.

Safety services give additional functions to four described categories (Fig. 1).

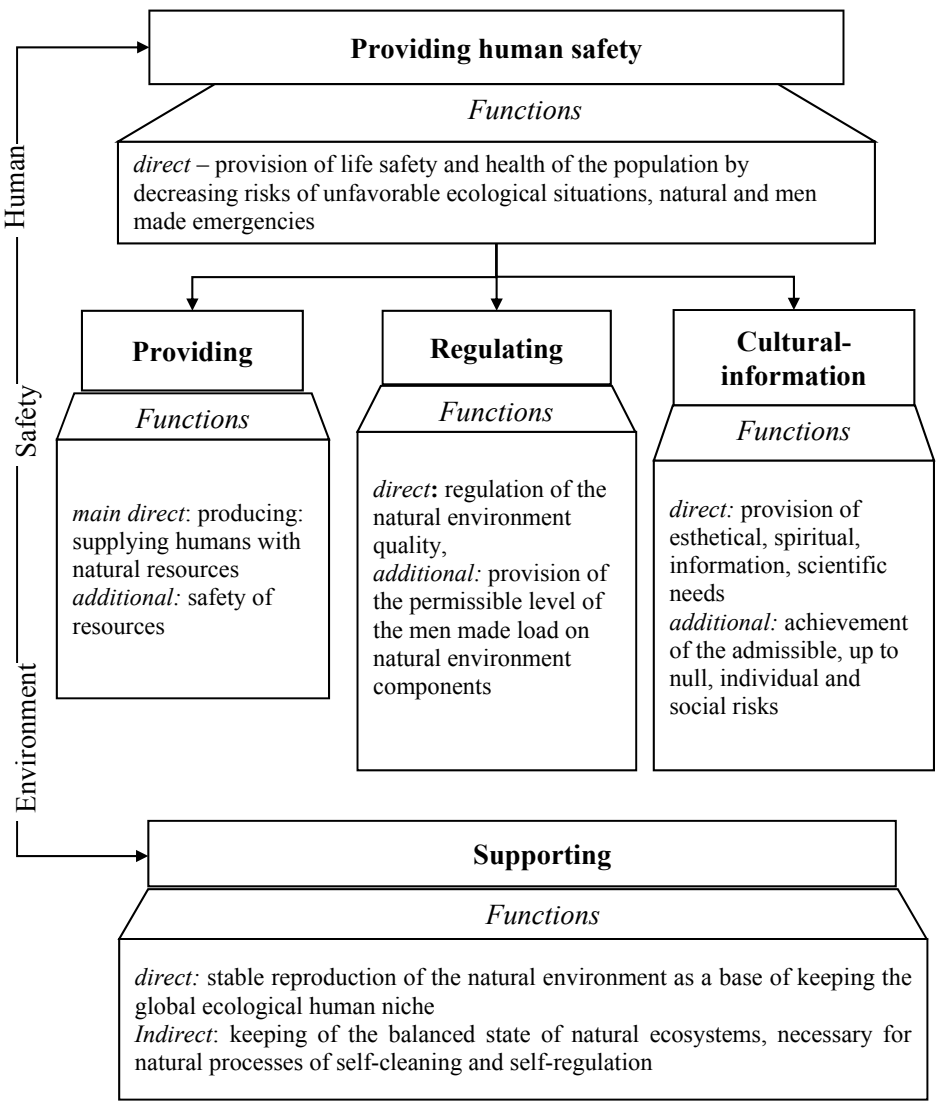

Fig. 1. The scheme of ecological services of the urboecosystem with the integral service of human and environmental safety 
Thus, productive functions in the category of providing services must supply a human with products, given by nature - clean water, vegetable food, vegetable raw materials and many others. But these products must not damage human life and health and must correspond to certain safety norms and standards. Such standards exist in all countries, they include standards of drinking water, content of heavy metals, carcinogenic, toxic, genetically modified substances in food products. The radiological content of any goods, subjects of accommodations, everyday life, recreation is also compulsory. Humans' provision with products of the natural origin taking into account rigid norms and rules of their quality allows to add providing services with the special function of resource safety.

Regulating functions are based on the ability of natural elements to assimilate pollutions, in such a way compensating negative effects. Different types of plants in the complex realize the widest spectrum of functions on regulating the mesoclimate, decreasing the acoustic load, phytoremediation of soil (that is very important for territories of wastes storage). Certain types of producers are used in anti-landslide, anti-karst arrangements, protection against underflooding and landslides formation. Thus, the green infrastructure of a city is used for both prevention of unfavorable events (up to emergencies) of the men made and natural origin and for minimization of their results.

But only stable ecosystems have the full set of ecosystem functions. Compensatory-regulating abilities for any environmental components depend on a measure of external impacts. At disturbing load thresholds, abilities to self-purification, self-regulation, self-restoration, fixed for water bodies, atmospheric air, are exhausted. At that volumes of wastes, processed by the natural way, abruptly decrease. A profit from using functions becomes a loss, compensatory expenditures and restoration ones. Such approach is completely described by the categories of assimilation capacity of the environment and permissible measure of its use in the anthropogenic channel.

Thus, the service for providing just human safety and health includes keeping regulating services that is providing the human habitat quality at a certain level. Functions of providing safety for supporting services are divided in two groups. The first one includes keeping balance of the natural system as a base of its safety existence and reproduction. The second one is connected with the necessity to keep a certain part of the territory as "wild nature". This group includes functions of city planning, keeping "green girdles" of a city, objects of the ecological net.

\section{Discussion. Identification of functions of the safety service and ways of formation of eco- logical estimations}

The succession of steps for identifying functions of safety services, determination of indicators and correspondent ecological-economic methods of estimation is presented on Fig. 2.

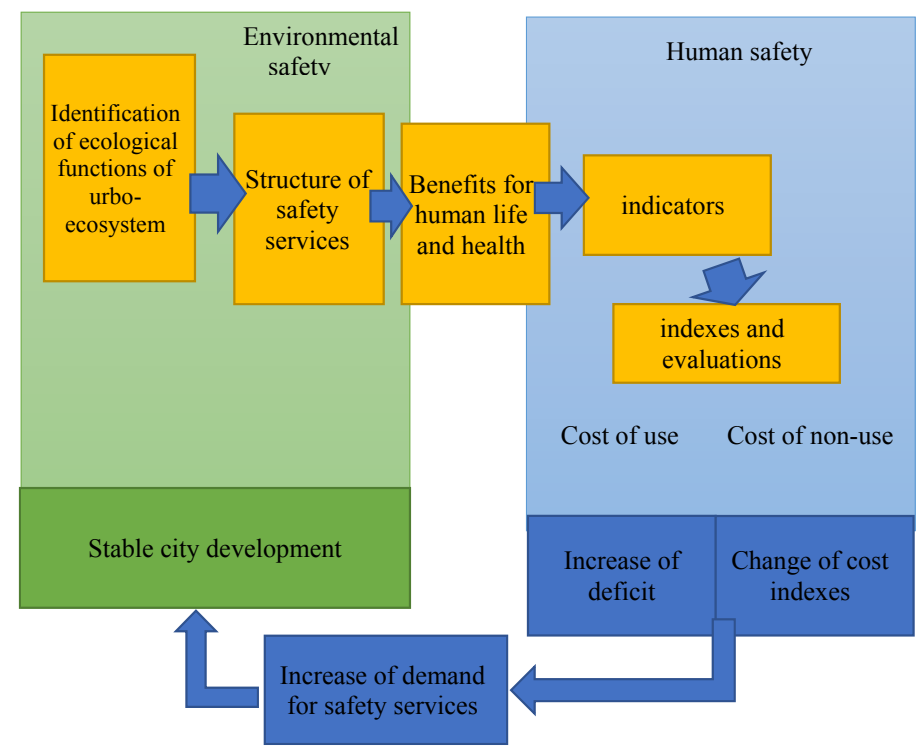

Fig. 2. The scheme of steps succession for identifying and evaluation safety services 
A city as a complicated scheme realizes a complex pressure on the landscape in whole. It results in the important redistribution of functions of ecological services. Provision of the demand for safety services corresponds to the stable development of cities. It means keeping a structure and abilities to compensate men made impacts, balance natural processes, negative for a human, by the urboecosystem.

Nevertheless, production of almost all types of providing, regulating, cultural and household and, especially, supporting services is as if "beyond the city line" and is torn from potential beneficiaries. As a result, the system of economic estimations of human benefits from obtaining and losses from deficiency will change. Besides, non-monetary parameters can change more essentially than monetary ones.

The demand for safety within the urboecosystem will inevitably grow or remain at the constantly high level. It is connected with two factors:

1 - The growth of human welfare is connected with higher safety requirements.

2 - The progressing growth of toxicity and danger of a habitat raises risks for human life and health.

Thus, economic estimations of ecological services may include risk-oriented approaches, may be determined by losses, optimized expenditures for preventing and compensating risks.

Each function of the urboecosystem taking into account concrete conditions and factors of the urban landscape needs elaboration of indicators with correspondent indices of estimations. Table 1 presents several main functions that directly provide human and urban environment safety. The table demonstrates that one function usually supports several services. At that it is characterized by one set of indicators and ecological-economic estimations.

Table 1

The set of parameters of the system of eco-services with included safety services

\begin{tabular}{|c|c|c|c|}
\hline Functions & $\begin{array}{l}\text { Ecological } \\
\text { services }\end{array}$ & Indicators & $\begin{array}{l}\text { Character of ecological- } \\
\text { economic estimation }\end{array}$ \\
\hline $\begin{array}{l}\text { Support of parameters } \\
\text { of the urban envi- } \\
\text { ronment, optimal for } \\
\text { human health }\end{array}$ & $\begin{array}{l}\text { Safety's Reg- } \\
\text { ulating Cul- } \\
\text { tural-spiritual, } \\
\text { Supporting }\end{array}$ & $\begin{array}{l}\text { Morbidity/mortality indexes comparing with } \\
\text { average ones in the region, country, WHO (world } \\
\text { Health Organization) estimations. } \\
\text { indexes of cancer morbidity/mortality. Indexes } \\
\text { of endemic and professional diseases. Average } \\
\text { life duration, comparing with average one in the } \\
\text { region, country, WHO estimations }\end{array}$ & $\begin{array}{l}\text { Parameters of city budgets in } \\
\text { different sections of health pro- } \\
\text { tection, environment protection } \\
\text { and development of the green } \\
\text { infrastructure. } \\
\text { Investments in profile programs. } \\
\text { Volumes of economic funds }\end{array}$ \\
\hline $\begin{array}{l}\text { Prevention of natural } \\
\text { emergencies, minimi- } \\
\text { zation of consequences }\end{array}$ & $\begin{array}{l}\text { Safeties } \\
\text { Regulating } \\
\text { Supporting }\end{array}$ & $\begin{array}{l}\text { Specific parameters of territories of underflood- } \\
\text { ing, landslides, karsts and other dangerous disas- } \\
\text { ters taking into account their changes in time. } \\
\text { Specific number (per territory sizes) of fires in } \\
\text { suburban forests, peatbogs taking into account } \\
\text { the time factor. } \\
\text { Statistic data of natural disasters and emergen- } \\
\text { cies in regional, national and international scales }\end{array}$ & $\begin{array}{l}\text { Estimations of material and } \\
\text { human losses from natural } \\
\text { emergencies. } \\
\text { Estimations of compensations as } \\
\text { a result of natural calamities and } \\
\text { emergencies. Volumes of profile } \\
\text { ecological programs and funds }\end{array}$ \\
\hline $\begin{array}{c}\text { Prevention of men } \\
\text { made emergencies, } \\
\text { minimization of results }\end{array}$ & $\begin{array}{l}\text { Safeties } \\
\text { Regulating }\end{array}$ & $\begin{array}{l}\text { Number of extremely dangerous objects within } \\
\text { a city. } \\
\text { Number of potentially dangerous objects within } \\
\text { an urban agglomeration. } \\
\text { Specific parameters of the number and types of } \\
\text { men made emergencies }\end{array}$ & $\begin{array}{l}\text { Number of accidents that result- } \\
\text { ed in human death or traumas, } \\
\text { material losses. } \\
\text { Estimations of losses, caused to } \\
\text { human health/natural environ- } \\
\text { ment }\end{array}$ \\
\hline $\begin{array}{l}\text { Decrease of risks of } \\
\text { natural environment } \\
\text { pollution }\end{array}$ & $\begin{array}{l}\text { Safeties } \\
\text { Providing } \\
\text { Regulating } \\
\text { Supporting }\end{array}$ & $\begin{array}{l}\text { Specific volumes of emissions, dumping, solid } \\
\text { wastes per head of the urban population. } \\
\text { Specific area of dumps of solid domestic wastes. } \\
\text { Degree of utilization and recuperation of wastes. } \\
\text { Volumes of dangerous and radioactive wastes, } \\
\text { type of changes by years. } \\
\text { Density Indexes of motor transport }\end{array}$ & $\begin{array}{l}\text { Financial reporting of compen- } \\
\text { satory payments as a result of } \\
\text { natural environment pollution, } \\
\text { violation of ecological and na- } \\
\text { ture protecting legislation. } \\
\text { Volumes of ecological programs } \\
\text { and funds. }\end{array}$ \\
\hline
\end{tabular}


As an example, let's consider population's provision with water. This function of a providing service is in giving sweet water, necessary for the human life activity by the ecosystem of a natural water body. In the aspect of a safety service an additional function just of safety of a drinking resource and correspondence to quality standards appears. But the structure of a service also includes:

1. In the block of cultural services - reaching the physiological optimum of water. An indicator may be both the degree of correspondence of the service to national and international standards of drinking water and parameters of the influence of the drinking water composition on population's health. Let's note the high social value of fresh water.

2. In the block of functions of regulating services - preservation of natural ecosystems, especially forests [25], in a basin of water intake. Indicators of a function are ecological estimations of the state of a basin, categories of water quality, parameters of the ability to self-purification. The economic estimation of benefits is connected with optimization of expenditures for water treatment.

3. In the block of supporting system - restoration of water volumes at the expanse of natural processes. An indicator is conditioned by the water balance of a water reservoir, and economic estimation - by the consumer cost of water as a resource.

Let's note that regulating and supporting services are combined on the platform of safety from the positions of preventing spontaneous and anthropogenic negative, such as floods, landslides, soils pollution, bog reclamation, disafforestation at the territory of a water intake basin. All these processes and emergencies worsen parameters of the ecosystem of a water body that, as a whole, shortens the potential of a service and raises its cost for a human.

It may be stated, that services of human and habitat safety will improve other services from both positions of their quality and widening of the assortment. From our point of view, it is especially promising to estimate the potential of the green infrastructure of a city for getting benefits for realizing the set of urboecosystem functions. The diversity and mutual dependence of functions of urboecosystems, providing services of different categories, also increase. In total, the separation and provision of safety services increase the general potential of eco-services of urboecosystems.

\section{Conclusions}

The work presents the conception of the ecological safety services as a new type of eco-services under conditions of accelerated urbanization.

There are determined connections between urbanization, degradation of the environment and human needs in services for providing safety in a habitat.

Separation of the new integral safety service is based on the principle of providing human safety through the environmental one. It is demonstrated, that the new category of ecosystem services allows to estimate benefits and losses from using the whole system of natural, anthropogenic and men made factors of a habitat by a human.

The presented block-scheme of ecological services demonstrates that services of human and habitat safety will improve other services from both positions of their quality and widening of the assortment. The diversity and mutual dependence of functions of urboecosystems, providing services of different categories, also increase.

There was presented the succession of steps for identifying and estimating safety services. Indicators and possible types of giving safe and high-quality drinking water to the population were given.

Thus, separation and provision of safety services provide the general potential of eco-services, and human vitally important needs are provided by natural environment safety.

\section{References}

[1] Ukrayina u tsyfrakh (2016). Derzhavna sluzhba statystyky Ukrayiny. Kyiv, 240. Available at: http://www.ukrstat.gov.ua/druk/publicat/kat_u/publ1_u.htm 
[2] Ukrayina: Ohlyad urbanizatsiyi (2015). The World Bank. Washington DC, 218. Available at: https://www.slideshare.net/Mistosite/ss-66014065

[3] Li, Y., Li, Y., Zhou, Y., Shi, Y., Zhu, X. (2012). Investigation of a coupling model of coordination between urbanization and the environment. Journal of Environmental Management, 98, 127-133. doi: 10.1016/j.jenvman.2011.12.025

[4] Daily, G. (Ed.) (1997). Nature's Services: Societal Dependence on Natural Ecosystems., Washington D.C.: Island Press, 392. Available at: https://scholar.google.com/scholar?q=GRETCH$\mathrm{EN}+\mathrm{C} .+\mathrm{DAILY}+\% 28 \mathrm{Ed} . \% 29+\mathrm{Nature} \% 27 \mathrm{~s}+$ Services $\% 3 \mathrm{~A}+$ Societal+Dependence $+\mathrm{on}+\mathrm{Natural}+$ Ecosystems

[5] Millennium Ecosystem Assessment. Ecosystems and Human Well-being. Synthesis Report (2005). Washington D.C.: Island Press, 160. Available at: https://www.millenniumassessment.org/documents/document.356.aspx.pdf/

[6] de Groot, R. et. al. (2010). The Economics of Ecosystems and Biodiversity: Ecological and Economic Foundation. Cambridge: Earthscan, 40. Available at: http://www.profwillemvanriet.com/images/D0-Chapter-1-Integrating-the-ecological-and-economic-dimensions-in-biodiversity-and-ecosystem-service-valuation_2.pdf

[7] Maes, J., Teller, A., Erhard, M., Liquete, C., Braat, L. et. al. (2013). Mapping and Assessment of Ecosystems and their Services. An Analytical Framework for Ecosystem Assessments under Action 5 of the EU Biodiversity Strategy to 2020. Discussion Paper. Luxembourg: European Union, 57. Available at: http://ec.europa.eu/environment/nature/knowledge/ecosystem_assessment/pdf/MAES WorkingPaper2013.pdf

[8] Maes, J., Teller, A., Erhard, M., Murphy, P., Paracchini, M. L. et. al. (2014). Mapping and Assessment of Ecosystems and their Services. Indicators for Ecosystem Assessments under Action 5 of the EU Biodiversity Strategy to 2020. 2nd Report. Brussels: European Union, 80. Available at: http:// ec.europa.eu/environment/nature/knowledge/ecosystem_assessment/pdf/2ndMAESWorkingPaper.pdf

[9] Diehl, K., Burkhard, B., Jacob, K. (2016). Should the ecosystem services concept be used in European Commission impact assessment? Ecological Indicators, 61, 6-17. doi: 10.1016/ j.ecolind.2015.07.013

[10] Heink, U., Hauck, J., Jax, K., Sukopp, U. (2016). Requirements for the selection of ecosystem service indicators - The case of MAES indicators. Ecological Indicators, 61, 18-26. doi: 10.1016/ j.ecolind.2015.09.031

[11] Reyers, B., Biggs, R., Cumming, G. S., Elmqvist, T., Hejnowicz, A. P., Polasky, S. (2013). Getting the measure of ecosystem services: a social-ecological approach. Frontiers in Ecology and the Environment, 11 (5), 268-273. doi: 10.1890/120144

[12] Layke, C., Mapendembe, A., Brown, C., Walpole, M., Winn, J. (2012). Indicators from the global and sub-global Millennium Ecosystem Assessments: An analysis and next steps. Ecological Indicators, 17, 77-87. doi: 10.1016/j.ecolind.2011.04.025

[13] Schetke, S., Lee, H., Graf, W., Lautenbach, S. (2018). Application of the ecosystem service concept for climate protection in Germany. Ecosystem Services, 29, 294-305. doi: 10.1016/j.ecoser.2016.12.017

[14] Eigenbrod, F., Bell, V. A., Davies, H. N., Heinemeyer, A., Armsworth, P. R., Gaston, K. J. (2011). The impact of projected increases in urbanization on ecosystem services. Proceedings of the Royal Society B: Biological Sciences, 278 (1722), 3201-3208. doi: 10.1098/rspb.2010.2754

[15] Alcamo, J., van Vuuren, D., Ringler, C., Cramer, W., Masui, T., Alder, J., Schulze, K. (2005). Changes in nature's balance sheet: model-based estimates of future worldwide ecosystem services. Ecology and Society, 10 (2). doi: 10.5751/es-01551-100219

[16] Long, H., Liu, Y., Hou, X., Li, T., Li, Y. (2014). Effects of land use transitions due to rapid urbanization on ecosystem services: Implications for urban planning in the new developing area of China. Habitat International, 44, 536-544. doi: 10.1016/j.habitatint.2014.10.011

[17] Su, S., Xiao, R., Jiang, Z., Zhang, Y. (2012). Characterizing landscape pattern and ecosystem service value changes for urbanization impacts at an eco-regional scale. Applied Geography, 34, 295-305. doi: 10.1016/j.apgeog.2011.12.001 
[18] Bolund, P., Hunhammar, S. (1999). Ecosystem services in urban areas. Ecological Economics, 29 (2), 293-301. doi: 10.1016/s0921-8009(99)00013-0

[19] Andersson, E., Barthel, S., Borgstrom, S., Colding, J., Elmqvist, T., Folke, C., Gren, A. (2014). Reconnecting Cities to the Biosphere: Stewardship of Green Infrastructure and Urban Ecosystem Services. AMBIO, 43 (4), 445-453. doi: 10.1007/s13280-014-0506-y

[20] Pataki, D. E., Carreiro, M. M., Cherrier, J., Grulke, N. E., Jennings, V., Pincetl, S. et. al. (2011). Coupling biogeochemical cycles in urban environments: ecosystem services, green solutions, and misconceptions. Frontiers in Ecology and the Environment, 9 (1), 27-36. doi: 10.1890/090220

[21] Badiu, D. L., Ioja, C. I., Patroescu, M., Breuste, J., Artmann, M., Nita, M. R. et. al. (2016). Is urban green space per capita a valuable target to achieve cities' sustainability goals? Romania as a case study. Ecological Indicators, 70, 53-66. doi: 10.1016/j.ecolind.2016.05.044

[22] Litvinova, A. A., Ignateva, M. N., Koroteev, G. D. (2016). The concept of ecosystem functions and services. Economics and Society, 3 (22). Available at: http://docplayer.ru/33908767-Ponyatie-ekosistemnyh-funkciy-i-uslug.html

[23] Ecosystem services of terrestrial ecosystems in Russia: first steps (2013). Status Quo Report. Moscow: Wildlife Conservation Center, 45. Available at: https://www.biodiversity.ru/programs/ ecoservices/first-steps/Status_Quo_Report_2013_sm.pdf

[24] Sotnik, I. N., Mohilenets, T. V. (2011). Analyz podkhodov k ekonomycheskoi otsenke ekosystemnykh usluh. Mekhanizm rehuliuvannia ekonomiky, 2, 152-158. Available at: http://mer.fem.sumdu.edu.ua/content/acticles/issue_13/I_M_Sotnyk_T_V_MogilenetsAnalysis_of_ecosystem_services_ economical_valuation_approaches.pdf

[25] Soloviy, I. (2016). Evaluation of forest ecosystem services provided by forests of Ukraine and proposals on PES mechanisms. Enpi East Fleg II, 92. Available at: http://sfmu.org.ua/files/Soloviy_2016b.pdf 